\title{
Optimization of Physical and Nutritional Factors for Enhanced Production of Lignocellulolytic Enzymes by Aspergillus terreus FJAT-31011 under Submerged Conditions
}

\author{
Tanvi*, Suman Chaudhary, Rinku Dhanker, Sushila Devi and Sneh Goyal
}

Department of Microbiology, CCS Haryana Agricultural University, Hisar-125004, Haryana, India

Corresponding author

\section{A B S T R A C T}

\begin{tabular}{|c|c|}
\hline Keywo & \multirow{4}{*}{$\begin{array}{l}\text { Fungi are commonly used in biotechnological and environmental processes through } \\
\text { exploitation of their natural catalytic activities. One such fungal activity is to degrade } \\
\text { lignocellulosic biomass by producing certain extracellular enzymes. In this study an } \\
\text { indigenous white rot fungus SMT } 29 \text { isolated from compost sample was used under } \\
\text { submerged conditions for lignocellulolytic enzyme production. The process for } \\
\text { lignocellulolytic enzyme production was improved by optimizing certain physical and } \\
\text { nutritional parameters. In the present study, enzyme production by the fungus was } \\
\text { substantially improved to } 0.086 \mathrm{IU} / \mathrm{ml}(\mathrm{FPase}), 0.015 \mathrm{IU} / \mathrm{mL} \text { (CMCase), } 10.5 \mathrm{IU} / \mathrm{mL} \\
(\mathrm{Lac}), 65.2 \mathrm{IU} / \mathrm{mL}(\mathrm{LiP}) \text { and } 6 \mathrm{IU} / \mathrm{mL}(\mathrm{MnP}) \text { at } 30^{\circ} \mathrm{C}, 6 \mathrm{pH} \text {, on } 7^{\text {th }} \text { day of incubation with } \\
200 \mathrm{mg} / \mathrm{L} \mathrm{CMC} \mathrm{powder} \mathrm{(in} \mathrm{Mery} \mathrm{Mendels} \mathrm{broth,} \mathrm{for} \mathrm{cellulolytic} \mathrm{activity)} \mathrm{and} 200 \mathrm{mg} / \mathrm{L} \\
\text { alkali lignin (in Malt extract agar broth for ligninolytic activity) as carbon source and } 0.5 \\
\text { g/L ammonium sulfate in as nitrogen source. }\end{array}$} \\
\hline & \\
\hline Articl & \\
\hline & \\
\hline
\end{tabular}

\section{Introduction}

Although the history of lignin and cellulose chemistry is old with voluminous amounts of literature (Barton, 1998), the recalcitrant nature of lignin still limits the availability of cellulose biomass for biological systems to work on it. Cellulose, the major fraction of lignocellulosic biomass, can be hydrolyzed to glucose by cellulase enzymes. However, the key obstacle for transitioning lignocellulosic feedstock is the presence of lignin in them, which retards the artificial cellulases during the cellulose hydrolysis. Due to its complex aromatic heteropolymer and high molecular weight, lignin is extremely recalcitrant to biodegradation (Zhao et al., 2012).

Many microorganisms that produce lignocellulolytic enzymes have been studied for many decades. Some members of all classes of microorganisms, viz., fungi, actinomycetes and bacteria are known to produce ligninase and cellulase isoforms (Kubicek, 2008). However, fungal enzymes are generally complete comprising all the 
lignocellulolytic activities. Furthermore, fungal enzymes are usually preferred because they are extra-cellular, adaptive and usually secreted in large quantities during growth to the tune of $2 \%$ by weight.

Cellulases hydrolyze the $\beta$-1,4-glycosidic linkages of cellulose. Endoglucanases break internal bonds in cellulose chains; preferably in cellulose amorphous regions releasing new terminal ends whereas exoglucanases break cellulose bonds near exposed ends of cellulose resulting in disaccharides called cellobiose; that act on the existing or endoglucanases generated chain ends, preferably in cellulose crystalline regions. Fungi degrade lignin by secreting enzymes collectively termed "ligninases". Ligninases can be classified as either phenol oxidases (laccase) or heme peroxidases [lignin peroxidase (LiP), manganese peroxidase $(\mathrm{MnP})$, versatile peroxidase (VP)] (Martinez et al., 2005). In general, laccases use molecular oxygen as electron acceptors while peroxidases use hydrogen peroxide as a co-substrate (Mai et al., 2004). Besides these, fungi secrete some other lignin degrading enzymes also but studies have been done extensively on laccase, lignin peroxidase and manganese peroxidase. The expression system of oxidative enzymes of white-rot fungi is highly regulated by the nutrients that the fungi are exposed to, so that if a fungus can grow on a medium supplemented with lignin, it may produce extracellular enzyme(s) that can promote degradation/ modification of lignin or ligninderived components. Secondly, if such enzyme activity would be supplemented to a lignocellulosic substrate undergoing cellulolytic hydrolysis, then the added enzyme activity might boost the conversion of the cellulose (Sitarz et al., 2013).

Lignocellulolytic fungi are often divided into three groups, viz., white rot (degrade lignin), brown rot (degrade cellulose and hemicellulose) and soft rot fungi (degrade cellulose). The appropriate physicochemical conditions play an important role in the enzyme production by microorganisms. Media composition and fungal growth conditions strongly affect the production of ligninolytic and cellulolytic enzymes and the extent of lignocellulose degradation. Therefore, the objectives of this study were: 1) to isolate promising fungal species that can effectively produce lignocellulolytic enzymes, 2) to determine bio-physical conditions to enhance mycelial growth rate and effectiveness of selected Aspergillus species, 3) to compare the enzyme activity of selected Aspergillus species with standard cultures.

\section{Materials and Methods}

\section{Collection of samples}

Soil/compost samples were obtained from Centre for Plant Biotechnology (CPB), CCS Haryana Agricultural University, Hisar, Haryana

\section{Isolation and screening of lignocellulolytic fungi}

Selective techniques for enrichment and isolation of lignocellulolytic fungi from lignocelluloses rich ecological niches were performed. Enrichment was performed on liquid media consisting of Malt extract and Mary Mandel broth for ligninolytic and cellulolytic fungi respectively. The flasks were incubated at $28 \pm 2^{0} \mathrm{C}$ on rotary shaker at 140 rpm. After seven days, $1 \mathrm{ml}$ of each culture was withdrawn and a sequential dilution of enriched soil samples was prepared. This process was repeated two times using an incubation period of 14 days and, subsequently, microorganisms from enriched cultures were isolated on several specific solid media according to their degrading capacity. Cellulolytic activity was screened on Carboxy 
Methyl Cellulose (CMC) agar plates. Degradation of cellulose was visualized as a clear zone of hydrolysis around the fungal colony when after incubation the plates were flooded with $0.1 \%$ aqueous solution of congo red for 15-20 minutes followed by destaining with $1 \mathrm{M} \mathrm{NaCl}$ for 15-20 minutes. Diameter of the clear zone and colony were measured. Isolates were selected on the basis of the Index of Relative Enzyme Activity $\left(\mathrm{I}_{\mathrm{CMC}}\right)$. $\mathrm{I}_{\mathrm{CMC}}$ was calculated by the method of Bradner et al., (1999) and Peciulyte (2007).

$\mathrm{I}_{\mathrm{CMC}}=$

clear zone diameters surrounding the colony colony diameter

Ligninolytic microorganisms were screened by growing them on malt extract agar medium supplemented with $0.04 \%$ aniline blue dye. The decolorization zone was measured and zone of clearance was calculated by taking the ratio of clear zone diameter to colony diameter.

\section{Assay of enzymes}

Laccase, lignin peroxidase and manganese peroxidase production were measured with alkali lignin as substrate. CMCase and FPase production were measured with $\mathrm{CMC}$ and Whatman filter paper no. 1 as substrate respectively by the method described by Ghose (1987). Reducing sugars produced due to enzymatic actions were determined by 3,5dinitrosalicylic acid (DNS) method (Miller, 1959). One International Unit (IU) of enzyme was defined as the amount of enzyme required to liberate $1 \mu \mathrm{mol}$ of reducing sugars per minutes under the assay conditions.

\section{Physical conditions characterization}

Different physical conditions like temperature, $\mathrm{pH}$, aeration condition, incubation period, addition of metal ions, carbon and nitrogen sources were characterized. Fungal cultures were grown at temperatures 25,30 and $35^{\circ} \mathrm{C}$, $\mathrm{pH} \mathrm{4,} \mathrm{5,} 6$ and 7 and at stationary as well as shaking conditions and enzyme activities were determined by standard procedure. To check the relationship between enzyme activity and incubation period, samples from broth were withdrawn daily for 10 days. Three different metal ions $\mathrm{MnSO}_{4}, \mathrm{FeSO}_{4}$ and $\mathrm{ZnSO}_{4}$ were added in varying concentrations (Table 1 ) and their effect on different enzyme activities was studied using standard procedures.

Varying concentrations of different carbon sources (Table 2) were added to the respective broth to check their effect on enzyme activities.

Four ammonium salts viz., ammonium chloride, ammonium sulfate, ammonium nitrate and ammonium oxalate $(0.5 \mathrm{~g} / \mathrm{L})$ were added to the broth and their enzyme activities were determined by standard procedure.

Comparison of ligninolytic and cellulolytic activities of the selected isolate with standard culture

Standard cultures were obtained from MTCC, Institute of Microbial Technology (IMTECH), Chandigarh and Department of Microbiology, CCS HAU, Hisar. Their ligninolytic and cellulolytic activities were compared with the activity of selected fungal isolates.

\section{Morphological characterization}

For identification of fungal strain, morphology of fungal isolate such as colony color and size were monitored and recorded during the growth. Other fungal characteristics such as surface, margin and pigmentation, obverse and reverse morphology were also studied. The fungal specimen was stained with lactophenol cotton-blue, covered with cover slip and observed under 10X and 40X objectives of a 
compound microscope. The morphological characteristics such as septation and branching in hyphae, reproductive structures, sporulation and arrangement of spores etc. were studied. Fungal isolates were identified on the basis of above mentioned characteristics.

\section{Molecular characterization}

For molecular characterization, sample was outsourced to CHROMOUS BIOTECH PVT LTD., Bangalore, where the sample was subjected to PCR using 600-650 bp internal transcribed spacer (ITS) specific primers for $18 \mathrm{~S}$ rRNA. The gel purified sample was sequenced bidirectionally. The forward and reverse primars were aligned and analysed. The analysed sequence was subjected to BLAST using genebank (NCBI) for comparison. The sequence was submitted to genebank (NCBI) with accession number MH047280.

\section{Chemicals}

The chemicals and media ingredients were of AR and GR grade manufactured by Glaxo Laboratories Limited, Mumbai, E. Merck Limited, Worli, Mumbai, CDH Bioscience (P) Limited, New Delhi and Hi-media Laboratories (P) Limited, Mumbai. Alkali lignin was from Sigma-Aldrich, Bengaluru, India.

\section{Results and Discussion}

\section{Isolation and screening of fungi}

Selective enrichment and isolation technique led to the isolation of 4 mutually distinct fungi from compost sample collected from Centre for Plant Biotechnology (CPB), CCS HAU, Hisar. Fungal isolates SMT21 and SMT29 were giving lignocellulolytic activities after primary screening on malt extract agar medium containing aniline blue dye $(0.04 \%)$ and carboxy methyl cellulose agar plates
(Table 3). Whereas, isolates SMT5 and SMT13 were not showing any of these activities.

In a similar study, Charitha Devi et al., 2012 also used 1\% congo red solution followed by washing with $1 \mathrm{M} \mathrm{NaCl}$ and measuring the formation of yellow colour halo zone around the colony. Among 70 isolates, they selected 10 isolates for further studies on the basis of halo zone formation which varied from 16 to 48. However, Selvamet al., 2012 used poly R478 and remazol brilliant blue dyes for isolation and screening of ligninolytic fungi. The dye removal in 57 samples was in the range of 11.5 to $38.4 \%$ in poly- $\mathrm{R}$ dye and 11.1 to $72.0 \%$ in remazol brilliant blue.

\section{Physical conditions characterization}

In this study, at temperature $30^{\circ} \mathrm{C}$ (Fig. 1) and pH 6 (Fig. 2), the lignocellulolytic activity of SMT29 was maximum. Enzyme activities increased with increase in $\mathrm{pH}$ from 4 to 7 ; however, there were only slight differences in enzyme activities at pH 6 and 7 (Fig. 2). Also, during stationary conditions, enzyme activities were better as compared to that of shaking conditions with $0.015 \mathrm{IU} / \mathrm{ml}$ FPase and CMCase activity, $9.5 \mathrm{IU} / \mathrm{ml}$ lac, $54.34 \mathrm{IU} / \mathrm{ml}$ $\mathrm{LiP}$ and $5.5 \mathrm{IU} / \mathrm{ml} \mathrm{MnP}$ activity (Fig. 3). Some of the researchers have reported that shaking conditions are effective in lignocellulose degradation due to the production of more lignocellulolytic enzymes. On the contrary, few reports showed better lignocellulose degradation under static culture conditions (Roushdy and Abdel 2011; Balaji et al., 2012; Muthukumaran et al., 2014). Abdel-Fatah et al., 2012 determined the optimum cultural conditions for maximal carboxymethyl cellulase (CMCase) formation by Aspergillus terreus DSM 826 and they observed that shaking conditions at $150 \mathrm{rpm}$ was favorable for the production of CMCase from rice straw and sugar cane bagasse. 
Table.1 Metal ion concentrations for different enzyme activities

\begin{tabular}{|c|c|c|}
\hline \multirow[t]{2}{*}{ Metal ions } & \multicolumn{2}{|l|}{ Concentration $(\mathrm{g} / \mathrm{L})$} \\
\hline & For cellulase activity & For ligninases activity \\
\hline $\mathrm{MnSO}_{4}$ & $0.003,0.006,0.009$ & $0.25,0.51 .0$ \\
\hline $\mathrm{FeSO}_{4}$ & $0.0025,0.005,0.0075$ & $0.25,0.51 .0$ \\
\hline $\mathrm{ZnSO}_{4}$ & $0.0015,0.003,0.0045$ & $0.25,0.51 .0$ \\
\hline
\end{tabular}

Table.2 Different substrate concentrations for different enzyme activities

\begin{tabular}{|l|l|}
\hline Substrate & Concentration $(\mathrm{mg} / \mathrm{L})$ \\
\hline Alkali lignin & $50,100,200,300$ \\
\hline Cellulose powder & $50,100,200,300$ \\
\hline Carboxy Methyl Cellulose & $50,100,200,300$ \\
\hline
\end{tabular}

Table.3 Lignocellulolytic activities of fungal isolates

\begin{tabular}{l|c|c|c|c|}
\hline Fungal Isolate & $\begin{array}{c}\text { Ligninolytic } \\
\text { activity }\end{array}$ & $\begin{array}{c}\text { Zone of } \\
\text { clearance* }\end{array}$ & $\begin{array}{c}\text { Cellulolytic } \\
\text { Activity }\end{array}$ & $\mathrm{I}_{\mathrm{CMC}}{ }^{* *}$ \\
\hline SMT5 & - & 0.000 & - & 0.000 \\
\hline SMT13 & - & 0.000 & - & 0.000 \\
\hline SMT21 & + & 0.136 & ++ & 1.208 \\
\hline SMT29 & ++ & $\mathbf{1 . 0 5 6}$ & + & 0.745 \\
\hline
\end{tabular}
*Zone of clearance $=\frac{\text { total diameter (zone + colony) }}{\text { colony diameter }}$
** Index of relative CMCase activity (I (IMC)

Table.4 Cellulolytic and ligninolytic activities of SMT29 at different incubation period

\begin{tabular}{|l|l|l|l|l|l|}
\hline \multirow{2}{*}{$\begin{array}{l}\text { Incubation period } \\
\text { (Days) }\end{array}$} & \multicolumn{3}{|l|}{ Cellulolytic activities (IU/ml) } & \multicolumn{3}{|l|}{ Ligninolytic activities (IU/ml) } \\
\hline Day 2 & FPase & CMCase & Lac & LiP & MnP \\
\hline Day 3 & 0.027 & 0.000 & 2.50 & 4.50 & 0.50 \\
\hline Day 4 & 0.035 & 0.001 & 5.50 & 10.00 & 1.00 \\
\hline Day 5 & 0.021 & 0.003 & 6.00 & 10.50 & 1.00 \\
\hline Day 6 & 0.057 & 0.004 & 6.00 & 24.60 & 2.00 \\
\hline Day 7 & 0.063 & 0.004 & 10.50 & 58.50 & 4.00 \\
\hline Day 8 & 0.069 & 0.005 & 10.50 & 59.32 & 5.00 \\
\hline Day 9 & 0.065 & 0.003 & 10.10 & 47.64 & 3.00 \\
\hline Day 10 & 0.061 & 0.003 & 8.50 & 42.00 & 2.70 \\
\hline & 0.060 & 0.001 & 3.00 & 38.50 & 1.00 \\
\hline
\end{tabular}


Table.5 Cellulolytic and ligninolytic enzyme activities of selected fungal isolates at different $\mathrm{MnSO}_{4}$ concentrations

\begin{tabular}{|c|c|c|c|c|c|}
\hline \multirow[t]{2}{*}{ Fungal isolate } & \multicolumn{2}{|c|}{ Cellulolytic activities (IU/ml) } & \multicolumn{3}{|c|}{ Ligninolytic activities (IU/ml) } \\
\hline & FPase & CMCase & Lac & LiP & MnP \\
\hline & \multicolumn{2}{|c|}{$0.003 \mathrm{~g} / \mathrm{L}$} & \multicolumn{3}{|c|}{$0.25 \mathrm{~g} / \mathrm{L}$} \\
\hline \multirow[t]{2}{*}{ SMT29 } & 0.001 & 0.000 & 1.00 & 0 & 1 \\
\hline & \multicolumn{2}{|c|}{$0.006 \mathrm{~g} / \mathrm{L}$} & \multicolumn{3}{|c|}{$0.50 \mathrm{~g} / \mathrm{L}$} \\
\hline \multirow[t]{2}{*}{ SMT29 } & 0.015 & 0.015 & 0 & 29 & 0 \\
\hline & \multicolumn{2}{|c|}{$0.009 \mathrm{~g} / \mathrm{L}$} & \multicolumn{3}{|c|}{$1.00 \mathrm{~g} / \mathrm{L}$} \\
\hline SMT29 & 0.010 & 0.007 & 16 & 0 & 2 \\
\hline
\end{tabular}

Table.6 Cellulolytic and ligninolytic enzyme activities of selected fungal isolates at different $\mathrm{FeSO}_{4}$ concentrations

\begin{tabular}{|c|c|c|c|c|c|}
\hline \multirow[t]{2}{*}{ Fungal isolate } & \multicolumn{2}{|c|}{ Cellulolytic activities (IU/ml) } & \multicolumn{3}{|c|}{ Ligninolytic activities (IU/ml) } \\
\hline & FPase & CMCase & Lac & LiP & MnP \\
\hline & \multicolumn{2}{|c|}{$0.0025 \mathrm{~g} / \mathrm{L}$} & \multicolumn{3}{|c|}{$0.25 \mathrm{~g} / \mathrm{L}$} \\
\hline \multirow[t]{2}{*}{ SMT29 } & 0.006 & 0.007 & 0 & 0 & 1 \\
\hline & \multicolumn{2}{|c|}{$0.005 \mathrm{~g} / \mathrm{L}$} & \multicolumn{3}{|c|}{$0.50 \mathrm{~g} / \mathrm{L}$} \\
\hline \multirow[t]{2}{*}{ SMT29 } & 0.005 & 0.010 & 0 & 0 & 0 \\
\hline & \multicolumn{2}{|c|}{$0.0075 \mathrm{~g} / \mathrm{L}$} & \multicolumn{3}{|c|}{$1.00 \mathrm{~g} / \mathrm{L}$} \\
\hline SMT29 & 0.010 & 0.010 & 9 & 0 & 1 \\
\hline
\end{tabular}

Table.7 Cellulolytic and ligninolytic enzyme activities of selected fungal isolates at different $\mathrm{ZnSO}_{4}$ concentrations

\begin{tabular}{|c|c|c|c|c|c|}
\hline \multirow[t]{2}{*}{ Fungal isolate } & \multicolumn{2}{|c|}{ Cellulolytic activities (IU/ml) } & \multicolumn{3}{|c|}{ Ligninolytic activities (IU/ml) } \\
\hline & FPase & CMCase & Lac & LiP & MnP \\
\hline & \multicolumn{2}{|c|}{$0.0015 \mathrm{~g} / \mathrm{L}$} & \multicolumn{3}{|c|}{$0.25 \mathrm{~g} / \mathrm{L}$} \\
\hline \multirow[t]{2}{*}{ SMT29 } & 0.001 & 0.001 & 1 & 0 & 1 \\
\hline & \multicolumn{2}{|c|}{$0.003 \mathrm{~g} / \mathrm{L}$} & \multicolumn{3}{|c|}{$0.50 \mathrm{~g} / \mathrm{L}$} \\
\hline \multirow[t]{2}{*}{ SMT29 } & 0.010 & 0.005 & 8 & 7 & 1 \\
\hline & \multicolumn{2}{|c|}{$0.0045 \mathrm{~g} / \mathrm{L}$} & \multicolumn{3}{|c|}{$1.00 \mathrm{~g} / \mathrm{L}$} \\
\hline SMT29 & 0.014 & 0.011 & 18 & 4 & 4 \\
\hline
\end{tabular}


Table.8 Enzyme activities of selected fungal isolates at different concentrations of alkali lignin, CMC powder and cellulose powder

\begin{tabular}{|c|c|c|c|c|c|c|c|}
\hline \multirow[t]{2}{*}{ Fungal isolate } & \multicolumn{4}{|c|}{ Cellulolytic activities (IU/ml) } & \multicolumn{3}{|c|}{ Ligninolytic activities (IU/ml) } \\
\hline & FPase & CMCase & FPase & CMCase & Lac & LiP & MnP \\
\hline \multicolumn{8}{|c|}{$50 \mathrm{mg} / \mathrm{L}$} \\
\hline & \multicolumn{2}{|c|}{ Cellulose powder } & \multicolumn{2}{|c|}{ CMC powder } & \multicolumn{3}{|c|}{ Alkali lignin } \\
\hline SMT29 & 0.011 & 0.002 & 0.075 & 0.002 & 1.50 & 1.50 & 1.00 \\
\hline \multicolumn{8}{|c|}{$100 \mathrm{mg} / \mathrm{L}$} \\
\hline & \multicolumn{2}{|c|}{ Cellulose powder } & \multicolumn{2}{|c|}{ CMC powder } & \multicolumn{3}{|c|}{ Alkali lignin } \\
\hline SMT29 & 0.013 & 0.004 & 0.077 & 0.004 & 12.50 & 42.50 & 2.00 \\
\hline \multicolumn{8}{|c|}{$200 \mathrm{mg} / \mathrm{L}$} \\
\hline & \multicolumn{2}{|c|}{ Cellulose powder } & \multicolumn{2}{|c|}{ CMC powder } & \multicolumn{3}{|c|}{ Alkali lignin } \\
\hline SMT29 & 0.015 & 0.007 & 0.084 & 0.006 & 12.50 & 43.50 & 2.50 \\
\hline \multicolumn{8}{|c|}{$300 \mathrm{mg} / \mathrm{L}$} \\
\hline & \multicolumn{2}{|c|}{ Cellulose powder } & \multicolumn{2}{|c|}{ CMC powder } & \multicolumn{3}{|c|}{ Alkali lignin } \\
\hline SMT29 & 0.014 & 0.007 & 0.072 & 0.003 & 11.50 & 42.50 & 2.00 \\
\hline
\end{tabular}

Table.9 Comparison of different enzyme activities of selected isolates with standard isolates

\begin{tabular}{|l|l|l|l|l|l|}
\hline \multirow{2}{*}{ Fungal isolate } & \multicolumn{3}{|l|}{ Cellulolytic activities (IU/ml) } & \multicolumn{3}{l|}{ Ligninolytic activities (IU/ml) } \\
\cline { 2 - 6 } & FPase & CMCase & Lac & LiP & MnP \\
\hline SMT29 & 0.015 & 0.015 & 7.500 & 64.340 & 6.000 \\
\hline T. viride QM 9414 & 0.121 & 0.106 & 14.5 & 52.69 & 3.5 \\
\hline MTCC 787 & 0.080 & 0.029 & 0.50 & 93.500 & 6.210 \\
\hline C.D. at 5\% & 0.011 & 0.003 & 0.495 & 4.652 & 0.210 \\
\hline
\end{tabular}

Fig.1 Comparative study of different enzyme activities at different incubation temperatures
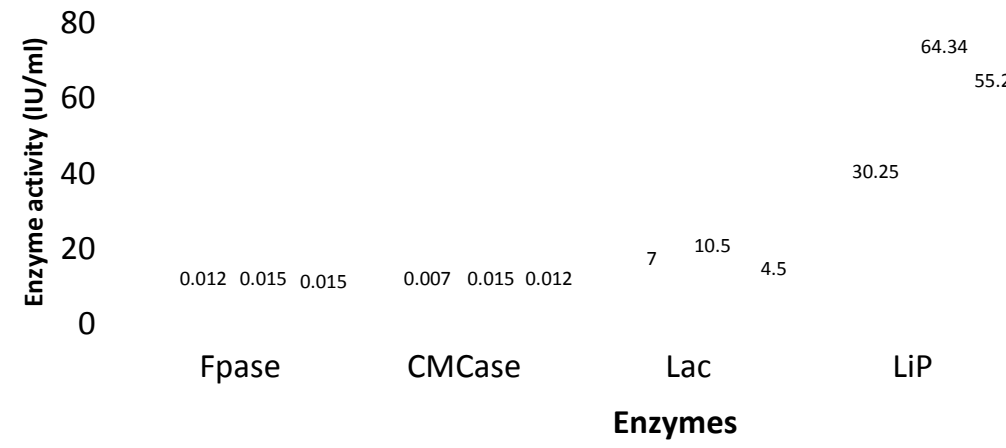

$25^{\circ} \mathrm{C}$

$30^{\circ} \mathrm{C}$

$35^{\circ} \mathrm{C}$ 
Fig.2 Comparative study of $\mathrm{pH}$ on different enzyme activities

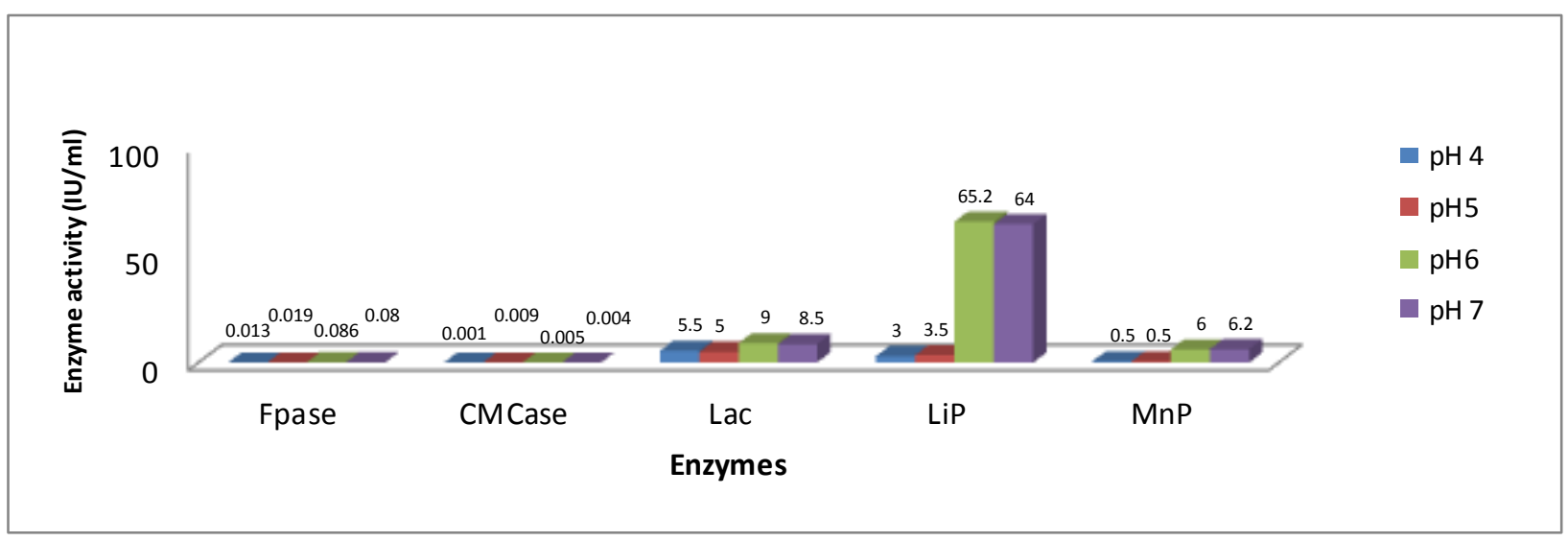

Fig.3 Comparative analysis of different enzyme activities at different aeration conditions

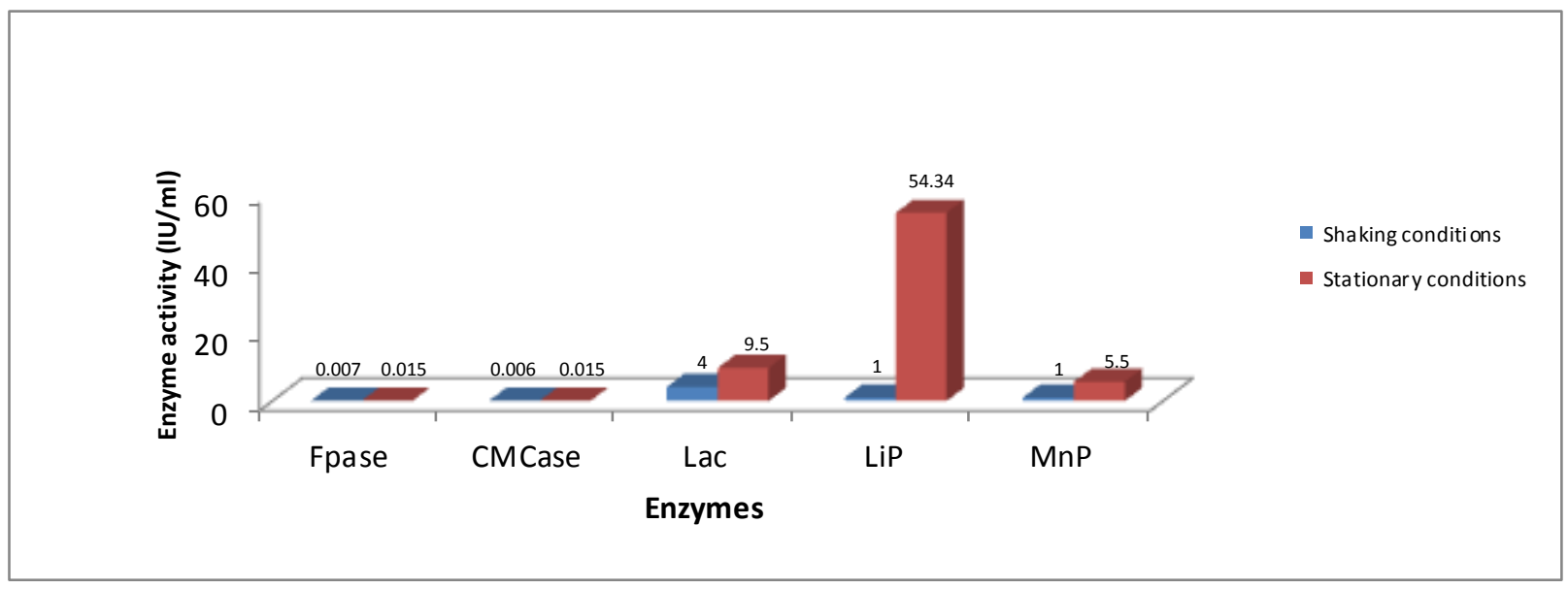

Fig.4 Comparative analysis of different enzyme activity at different concentration of ammonium salt

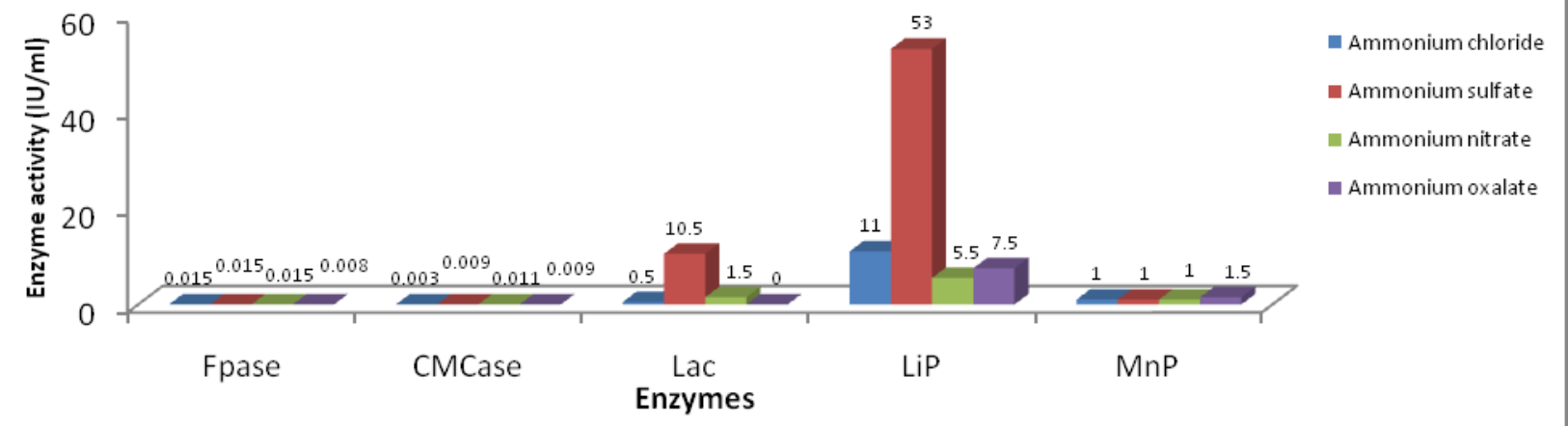


Fig.5 Morphology of SMT29

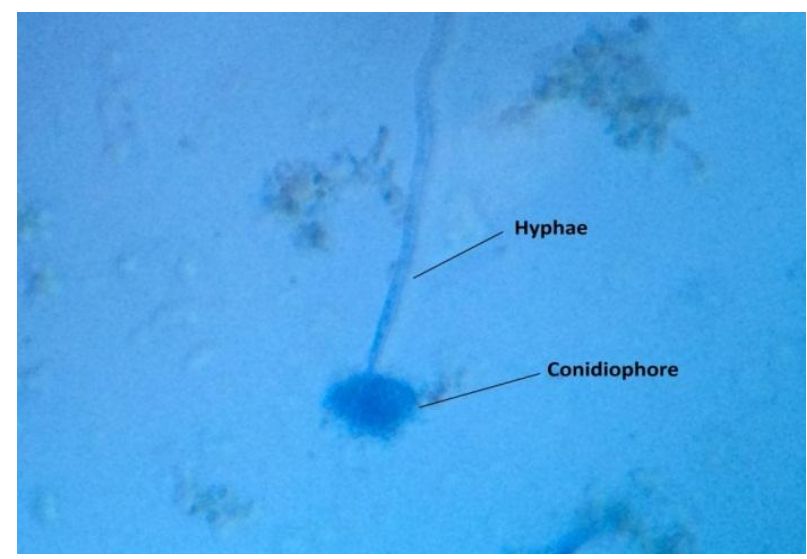

They also observed that highest enzyme yield was obtained at the third day of incubation at $30{ }^{\circ} \mathrm{C}$ for both cases; however CMCase formation occurred at a broad range of $\mathrm{pH}$ values, with maximal formation of $A$. terreus DSM 826 CMCase at $\mathrm{pH} 4.5$ and 5.0 when rice straw and sugar cane bagasse were used as sole carbon source, respectively. High level of enzyme formation was obtained with the addition of ammonium chloride as nitrogen source in both cases.

No enzyme activity was observed on $1^{\text {st }}$ day however, the enzyme activities increased with incubation period upto 7 days reaching a maximum value of $0.069 \mathrm{IU} / \mathrm{ml}$ FPase and $0.005 \mathrm{IU} / \mathrm{ml}$ CMCase and became almost constant afterwards. Similar trend was observed for laccase, lignin peroxidase and manganese peroxidase activity with maximum values of $10.5 \mathrm{IU} / \mathrm{ml}, 59.32 \mathrm{IU} / \mathrm{ml}$ and $5.00 \mathrm{IU} / \mathrm{ml}$ respectively on $7^{\text {th }}$ day of incubation. Therefore, all the enzyme activities were measured on $7^{\text {th }}$ day of incubation for further experiments (Table 4).

After addition of different concentrations of metal ions- $\mathrm{MnSO}_{4}, \quad \mathrm{FeSO}_{4}$ and $\mathrm{ZnSO}_{4}$ surprisingly all enzyme activities were found to decrease on addition of different metal ions in broth (Table 5, 6, and 7).
In a similar study, Guillén et al., in 2011 reported the effect of two metal ions - copper and cadmium on the ligninolytic and cellulolytic activities of 71 fungal isolates. They observed that majority of the fungal strains showed tolerance to $3 \mathrm{mM} \mathrm{Cu}$ in solid medium, but were inhibited by $1 \mathrm{mM} \mathrm{Cd}$.

From table 8 it was observed that lignocellulolytic activities increased with increase in substrate concentration upto 200 $\mathrm{mg} / \mathrm{L}$. Many other substrates like pre-treated groundnut shell (Vyas et al., 2005), oil palm empty fruit bunch fiber (Shahriarnour et al., 2011), coir waste (Mrudula and Murugammal, 2011) and rice straw and sugarcane bagasse (Abdel-Fatah et al., 2012; Kumar and Parikh, 2015) have also been reported for the production of cellulases by fungi. In a similar study by Kausar et al., 2010, the ability to degrade lignin and cellulose of ten lignocellulolytic isolates were tested and it was observed that their lignocellulolytic activity increased with increase in the concentration of substrate i.e. rice straw powder in the media, which showed the ability to utilize complex lignocellulosic materials in rice straw by producing oxidative and hydrolytic enzymes. Similarly, Neethu et al., (2012) fortified basal salt medium (BSM) with synthetic (carboxymethyl cellulose (CMC), glucose, sucrose, dextrose, 
lactose or maltose) and natural (flours of banana, banana peel, jack seed, potato or tapioca) carbon sources. They observed enhanced cellulase activity of $173 \mathrm{U} / \mathrm{mL}$ at $1.25 \%$ CMC concentration. Likewise, carboxymethyl cellulose (CMC) was found to be a good inducer for CMCase formation in both agricultural wastes with CMC concentrations of 0.5 and $1.0 \%(\mathrm{w} / \mathrm{v})$ in case of rice straw and sugar cane bagasse, respectively (Abdel-Fatah et al., 2012).Effect of substrate on enzyme production was also noticed by Naseebet al., 2015. They noted that carboxymethyl cellulose, salicin and xylan induced the production of endoglucanases, $\beta$ - glucosidase and xylanase respectively.

Nitrogen in the form of ammonium ions is easily accessible and act as nutrient for the growth of the fungi. This source is essential for the regeneration of NADH (Subramanian et al., 2014). Among four different ammonium salts added ammonium sulfate proved to be a better nitrogen source giving 0.015 FPase activity, $0.009 \mathrm{IU} / \mathrm{ml}$ CMCase, $10.5 \mathrm{IU} / \mathrm{ml}$ ac, $53 \mathrm{IU} / \mathrm{ml} \mathrm{LiP}$ and $1 \mathrm{IU} / \mathrm{ml}$ MnP activity (Fig. 4). Similarly, Membrillo et al.,(2016) also analyzed the effect of ammonium sulfate addition on lignocellulolytic enzymes production by 2 strains of Pleurotus ostreatus (IE-8 and CP50 and observed that strain CP-50 showed the highest increase of protein content $(48 \%$ on particle size of $1.68 \mathrm{~mm}$ ) when compared to media with no additional $\mathrm{N}$ source. However, strain IE-8 produced the highest levels of all enzymes: cellulases (0.18 IU/g dry wt on smallest particles), in case of both; with and without the addition of AS.

Comparison of ligninolytic and cellulolytic activity of the selected isolates with standard culture

Standard culture of Phanerochaete chrysosporium (MTCC 787) was procured from Microbial Type Culture Collection (MTCC), Institute of Microbial Technology (IMTECH), Chandigarh and Trichoderma viride QM 9414 was obtained from department of microbiology, CCS HAU, Hisar. Their ligninolytic and cellulolytic activities were compared with the activity of selected fungal isolates at optimized conditions (Table 9).

Among all the isolates compared with Standard cultures of MTCC 787 and T. viride QM 9414, the isolate SMT29 showed FPase and CMCase activities less in comparison to that of MTCC 787 and T. viride QM 9414. The isolate was showing > $6 \mathrm{IU} / \mathrm{ml}$ lac activity which was higher than the lac activity of MTCC 787 but less than the activity of $T$. viride $\mathrm{QM}$ 9414. However, LiP activity was more in the standard culture MTCC 787 (93.5 $\mathrm{IU} / \mathrm{ml}$ ) than the selected isolate. The MnP activity of SMT29 was equivalent to the standard cultures MTCC 787 and T. viride QM 9414 (Table 9). Mishra et al., 2007 also reported that the lignocellulolytic activities of two Phanerochaete chrysosporium strains (NCIM 1073 and MTCC 787) possessed higher CMCase (0.36 - $0.42 \mathrm{IU} \mathrm{ml}-1)$ and FPU (0.55 - 0.88 IU ml-1) activities after 15 days of submerged fermentation of paddy straw.P. chrysosporium 787 showed lignin peroxidase activity of $0.857 \mathrm{IU} / \mathrm{ml}$ and 1.477 $\mathrm{IU} / \mathrm{ml}$ after 7 and 15 days respectively, however, laccase activity of $0.116 \mathrm{IU} / \mathrm{ml}$ was recorded only after 15 daysof incubation.

\section{Morphological characterization}

SMT29 was showing full plate growth with flat yellow culture and brownish yellow spores. Hyphae were septate with separate conidia (Fig. 5). These morphological characteristics revealed that fungal isolate SMT29 belongs to phylum Ascomycota and it might be of the genus Aspergillus. 


\section{Molecular characterization}

After molecular analysis it was confirmed that the fungal strain is Aspergillus terreus FJAT31011 .

\section{Acknowledgement}

We greatly acknowledged the Department of Microbiology, College of Basic Sciences and Humanities, CCSHAU Hisar, Haryana, India for the help and support during execution of the experiments. We are highly thankful to the anonymous reviewers for their comments and suggestions which greatly enhanced the quality of old version

\section{References}

Abdel-Fatah, O.M., Hassan, M.M., Elshafei, A.M., Haroun, B.M., Atta, H.M. and Othman, A.M. (2012) Physiological studies on carboxymethyl cellulase formation by Aspergillus terreus DSM 826. Brazilian Journal of Microbiology. 43(1), 1-11.

Asgher, M., Bashir, F. and Iqbal, H.M.N. 2014. A comprehensive ligninolyticpre-treatment approach from lignocellulose green biotechnology to produce bio-ethanol. Chemical Engineering Research and Design 92, 1571-1578.

Balaji, V., Vinayagamoorthi, D., Palanisamy, A. and Anbalagan, S. (2012) Degradation of reactive red $\mathrm{HE} 7 \mathrm{~B}$ and yellow FN2R dyes by fungal isolates. Journal of Academia and Industrial Research, 1, 132-136.

Barton, II F.E. 1998. Chemistry of lignocellulose: methods of analysis and consequences of structure. Animal Feed Science and Technology. 21:279e86.

Bradner J.R., Gillings, M. and Nevalainen, K.M.H. (1999).Qualitative assessment of hydrolytic activities in Antarctic microfungi grown at different temperatures on solid media. World Journal of Microbiology and Biotechnology, 15, 131-132.

Charitha Devi, M. and Kumar, M.S. (2012) Isolation and screening of lignocellulose hydrolytic saprophytic fungi from dairy manure soil, Annals of Biological Research, 3(2),11451152.

Dashtban, M., Schraft, H., Syed, T.A. and Qin, W. 2010. Fungal biodegradation and enzymatic modification of lignin. International Journal of Biochemistry and Molecular Biology. 1:36e50.

Ghose, T.K. (1987). Measurement of cellulase activities.Pure and Applied Chemistry, 59, 257-268.

Guillén, Y., Palfner, G. and Machuca, A. (2011) Screening for lignocellulolytic enzymes and metal tolerance in isolates of wood-rot fungi from Chile, Interciencia, 36(11), 860-868.

Kausar, H., Sariah, M., Saud, H.M., Alam, M.Z. and Ismail, M.R. (2010) Development of compatible lignocellulolytic fungal consortium for rapid composting of rice straw. International Bioterioration and Biodegradation, 64(7), 594-600.

Kawaguchi, H., Hasunuma, T., Ogino, C. and Kondo, A. 2016. Bioprocessing of bio-based chemicals produced from lignocellulosic feedstocks. Current Opinion in Biotechnology. 42, 30-39.

Kubicek, C.P., Komon-Zelazowska, M. and Druzhinina, I.S. (2008) Fungal genus Hypocrea Trichoderma: From barcodes to biodiversity. Journal of Zhejiang University SCIENCE, 9, 753-763.

Kumar, A.K. and Parikh, B.S. (2015) Cellulose-degrading enzymes from Aspergillus terreus D34 and enzymatic saccharification of mild- 
alkali and dilute-acid pretreated lignocellulosic biomass residues. Bioresources and Bioprocessing, 2, 7.

Mai, C., Kues, U. and Militz, H. (2004).Biotechnology in the wood industry. Applied Microbiology and Biotechnology, 63, 477-494.

Martinez, A.T., Speranza, M., Ruiz-Duenas, F.J., Ferreira, P., Camarero, S., Guillen, F., Martinez, M.J., Gutierrez, A. and Rio, J.C. (2005). Biodegradation of lignocellulosics: microbial, chemical, and enzymatic aspects of the fungal attack of lignin. International Microbiology, 8, 195204.

Membrillo, I., Sa'nchez, C., Meneses, M., Favela, E. and Loera, O. (2008) Effect of substrate particle size and additional nitrogen source on production of lignocellulolytic enzymes by Pleurotus ostreatus strains, Bioresource Technology, 99, 7842-7847.

Miller, G.L. (1959) Use of dinitrosalicylic acid reagent for determination of reducing sugar. Analytical Chemistry, 31, 426-428.

Mishra, B.K. and Pandey Lata, A.K. (2007) Lignocellulolytic enzyme production from submerged fermentation of paddy straw. Indian Journal of Microbiology, 47, 176-179.

Mrudula, S. and Murugammal, R. (2011) Production of cellulose by Aspergillus nigerunder submerged and solid state fermentation using coir waste as a substrate. Brazilian Journal of Microbiology, 42(3), 1119-1127.

Muthukumaran, P., Priya, M., Divya, R., Indhumathi, E. and Keerthika, C. (2014) Biodecolorization of reactive dyes by using Pleurotus ostreatus. Journal of Biotechnology and Biosafety, 2, 94-101.

Naseeb, S., Sohail, M., Ahmad, A. \&Ahmed,
K.S.A. (2015) Production of xylanases and cellulases by Aspergillus fumigatus MS16 using crude lignocellulosic substrates. Pakistan Journal of Botany, 47(2), 779-784.

Neethu, K., Rubeena, M., Sajith, S., Sreedevi, S., Priji, P., Unni, K.N., Sarath Josh, M.K., Jisha, V.N., Pradeep, S. and Benjamin, S. (2012) A novel strain of Trichoderma viride shows complete lignocellulolytic activities, Advances in bioscience and Biotechnology, 3, 1160-1166.

Peciulyte, D. (2007) Isolation of cellulolytic fungi from waste paper gradual recycling materials Ecological, 53, 1118.

Ragauskas, A.J., Beckham, G.T., Biddiy, M.J., Chandra, R., Chen, F., Davis, M.F.,Davison, B.H., Dixon, R.A., Gilna, P., Keller, P., Langan, P., Naskar, A.K., Saddler, J.N., Tschaplinski, T.J., Tuskan, G.A., Wyan, C.E., 2014. Lignin valorization: improving lignin processing in the biorefinery. Science 344, 1246843.

Roushdy, M.M. and Abdel, E.H. (2011) Potential biotechnological application of lignin peroxidase produced by Cunninghamelia elegans in the decolorization and detoxification of malachite green dye. Brazilian Journal of Microbiology, 42, 15261536.

Selvam, K., Shanmuga Priya, M., Sivaraj, C. and Arungandhi, K. (2012) Identification and Screening of wood rot fungi from Western Ghats area of South India. International Journal of ChemTech Research, 4(1), 379-388.

Sharma, R.K. and Arora, D.S. 2015. Fungal degradation of lignocellulosic residue: an aspect of improved nutritive quality. Critical Reviews of Microbiology. 41:52e60. 
Shahriarinour, M., Wahab, M.N.A., Mustafa, S., Mohamad, R. and Ariff, A.B. (2011) Effect of various pretreatments of soil palm empty fruit bunch fibres for subsequent use as substrate on the performance of cellulase production by Aspergillus terreus. BioResource.6(1), 291-307.

Sitarz, A. K., Mikkelsen, J. D., Højrup, P. and Meyer, A. S. (2013) Identification of a laccase from Ganoderma lucidum CBS 229.93 having potential for enhancing cellulase catalyzed lignocellulose degradation. Enzyme and Microbial Technology.53,378385.

Subramanian, J., Ramesh, T. and Kalaiselvam, M. (2014) Degradation of triphenylmethane dye: malachite green by Aspergillus flavus. World Journal of Pharmacy and Pharmaceutical, 3, 44-50.

Vyas, A., Vyas, D. and Vyas, K.M. (2005) Production and optimization of cellulases on pretreated groundnut shell by Aspergillus terreus A V 49. Journal of Scientific and Industrial Research, 64, 281-286.

Zhao, X., Zhang, L. and Liu, D. (2012). Biomass recalcitrance. Part I: the chemical compositions and physical structures affecting the enzymatic hydrolysis of lignocellulose. Biofuels, Bioproducts and Biorefining, 6, 465482.

\section{How to cite this article:}

Tanvi, Suman Chaudhary, Rinku Dhanker, Sushila Devi and Sneh Goyal. 2018. Optimization of Physical and Nutritional Factors for Enhanced Production of Lignocellulolytic Enzymes by Aspergillus terreus FJAT-31011 under Submerged Conditions. Int.J.Curr.Microbiol.App.Sci. 7(07): 150-162. doi: https://doi.org/10.20546/ijcmas.2018.707.019 